\title{
CALCAREOUS NANNOFOSSILS BIOSTRATIGRAPHY OF JADDALA FORMATION IN WELL (AJEEL-10), CENTRAL IRAQ
}

\author{
Israa Sabah Al-Nuaimi* and Omar Ahmed Al-Badrani* \\ *Department of Geology, College of Science, Mosul University, Iraq. \\ *Corresponding author email: omarbadrani@uomosul.edu.iq
}

Received Date: 11 February 2021, Accepted Date: 24 May 2021, Published Date: 20 Jun 2021

\section{ABSTRACT}

A detailed systematic study of calcareous nannofossils was carried out for the Jaddala Formation in (Aj-10) well, Central Iraq. Seventy one species belong to twenty four genera of calcareous nannofossils were identified including sixty two of them were previously named and nine species were identified for the first time and they would not be given names until more information is obtained in the future to support this identification.

It is a recorded of five biostratigraphic zone, which suggested the age of the Jaddala Formation to be of early to late Eocene. The recorded biozone includes the following: Reticulofenestra dictyoda (Deflandre in Deflandre \& Fert, 1954) Stradner \& Edwards, 1968 Partial Range Biozone (CNE 5); Discoaster sublodoensis Bramlette and Sullivan, 1961 Interval biozone (CNE 6-7); Nannotetrina cristata (Martini, 1958) Perch-Nielsen, 1971 Interval biozone (CNE 8); Nannotetrina alata (Martini in Martini \& Stradner, 1960) Haq and Lohmann, 1976 Interval biozone (CNE 9); Chiasmolithus gigas Bramlette \& Sullivan, 1961Range Biozone (CNE 10-11).

Keywords: Biostratigraphy, Calcareous, Eocene, Iraq, Jaddala, Nannofossils.

\section{INTRODUCTION}

The Jaddala Formation was first described by Henson in 1940 near Jaddala village in north Iraq (Bellen et al., 1959). The Jaddala Formation outcrops showed up on narrow area of the Foothill Zone of Sinijar Mountain in the Northwestern of Iraq. It was occupied most of sediments in north areas during Eocene period and observed in most of subsurface sections with different thicknesses. The studied section from Ajeel well No. (10) is located $34^{\circ} 50^{\prime}$ 14.8" N. and 43 ${ }^{\circ} 53^{\prime} 59.0^{\prime \prime}$ E, North East of Tikrit City, Central Iraq (Map.1), within the Low Folded Zone belonging to Unstable Shelf of the Nubio-Arabian platform (Buday and Jassim, 1987). The sampled stratigraphic succession of the Jaddala Formation in this well (15 samples) consists of marly limestone. 
The stratigraphic succession of the Eocene in Iraq was studied based on the calcareous nannofossils by many authors such as Al-Badrani (2007); Al-Badrani (2011); Al-Badrani and Al-Nima (2010); Al-Badrani and Al-Ubaidi (2012) and Al-Badrani and Al-Zubaidi (2015, 2017, 2019 a and b). The aim of the present work is to determine the age of the Jaddala Formation by using calcareous nannofossils.

\section{MATERIALS AND METHODS}

A detailed study of calcareous nannofossils was carried out for stratigraphic successions of Jaddala Formation which is about $68 \mathrm{~m}$ and consists of marly limestone, overlies Aaliji Formation and underlies Oligocene Group. Fifteen cutting samples were used and examined under the light microscope. The extracted calcareous nannofossils were identified by using the Armstrong and Brasier (2005) methods for paleontological studies.

It is an extraction method for microfossils that can be properly examined when it is extracted from the rocks. The sample preparation included smear slides preparation which provides method for producing slides of calcareous nannofossils by placing a small amount of the disaggregated sample in distilled water and a drop of a dispersant. Then, the cover slip was left to dry on a warm hot plate. And to make permanent mounts, the slide and residue were allowed to dry at a low temperature away from possible sources of contamination. Finally, a drop of mounting medium (e.g. Canada balsam) was placed on a clean cover slip which in turn placed over the residue. Then, it was allowed to dry before examining under the transmitted light.

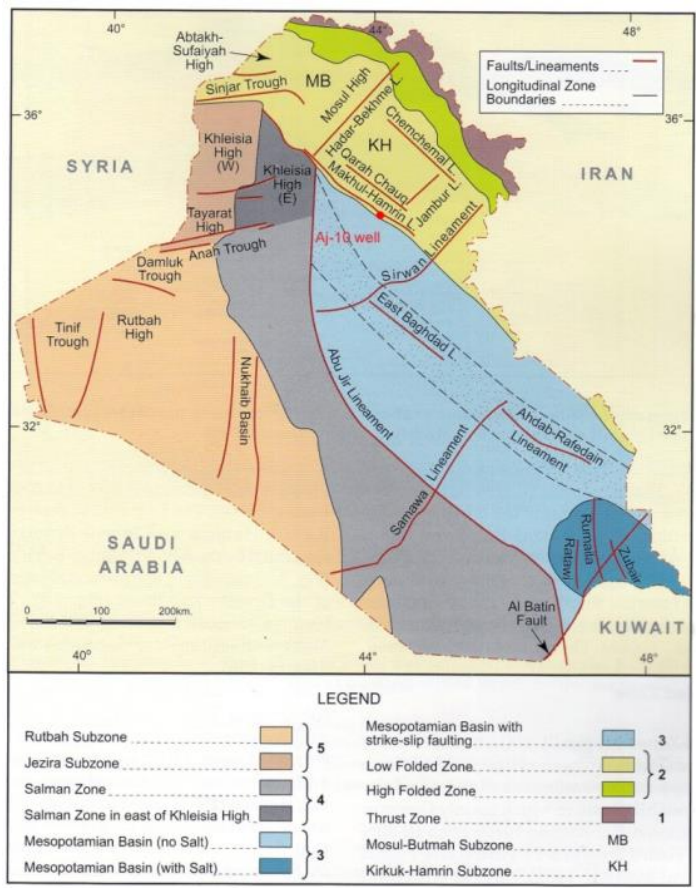

Map (1): Tectonic map of Iraq showing studied section (Jassim and Goff, 2006). 


\title{
RESULTS AND DISCUSSION
}

The aim of the systematic classification is to provide images of the notable calcareous nannofossils from the Tanjero Formation in Azmeranticline, Northern Iraq and to describe the seventy one species. All the observed taxa are listed below (Diag. 1). The higher taxonomy essentially follows the scheme of Young and Bown (1997) in addition to Perch-Nielsen's (1985). The material and images are stored at the Department of Geology, Science College, University of Mosul.

\author{
(A) Systematic and Classification \\ I-Heterococcoliths \\ Family: Helicosphaeraceae Black, 1971 \\ Genus: Helicosphaera Kamptner, 1954 \\ Helicosphaera ampliaperta Bramlette \& Wilcoxon, 1967(P1.1a) \\ Helicosphaera compacta Bramlette \& Wilcoxon, 1967(Pl.1b) \\ Helicosphaera lophota Bramlette \& Sullivan, 1961 (Pl.1c) \\ Helicosphaera papillata Bukry \& Bramlette, 1969 (Pl.1d) \\ Helicosphaera reticulata Bramlette \& Wilcoxon, 1967(P1.1e) \\ Helicosphaera salebrosa Perch-Nielsen, 1971 (Pl.1f) \\ Helicosphaera seminulum Bramlette \& Sullivan, 1961(Pl.1g) \\ Helicosphaera wilcoxonii (Gartner, 1971) Jafar \& Martini, 1975 (Pl.1h) \\ Helicosphaera sp. (Pl.1i)
}

Family: Pontosphaeraceae Lemmermann, 1908

Genus: Pontosphaera Lohmann, 1902

Pontosphaera distincta (Bramlette \& Sullivan, 1961) Roth \&Thierstein, 1972(Pl.1j)

Pontosphaera fimbriata ( Bramlette \& Sullivan, 1961) Romein, 1979(Pl.1k)

Pontosphaera multipora (Kamptner, 1948) Roth, 1970(Pl.1 1)

Pontosphaera ocellata (Bramlette \& Sullivan, 1961) Perch - Nielsen, 1984(Pl.2a)

Pontosphaera plana (Bramlette \& Sullivan, 1961) Haq, 1971(Pl.2b)

Pontosphaera scissura (Perch - Nielsen, 1971) Romein, 1979(Pl.2c)

Genus: Transversopontis Hay, Mohler \& Wade, 1966

Transversopontis prava Locker, 1967(Pl.2d)

Transversopontis $\mathrm{sp}$. (Pl.2e)

Family: Zygodiscaceae Hay \& Mohler, 1967

Genus: Lophodolithus Deflandre in Defalndre \& Fert, 1954

Lophodolithus nascens Bramlette \& Sullivan, 1961(Pl.2f)

Genus: Nannotetrina Achuthan \& Stradner, 1969

Nannotetrina alata (Martini in Martini \& Stradner, 1960) Haq \& Lohmann, 1976(Pl.2g)

Nannotetrina cristata (Martini, 1958) Perch - Nielsen, 1971(Pl.2h)

Nannotetrina quadrata (Bramlette \& Sullivan, 1961) Bukry, 1973(Pl.2i) 
Family: Rhabdosphaeraceae Lemmermann, 1908

Genus Blackites Hay \& Towe, 1962

Blackites inflatus (Bramlette \& Sullivan, 1961) Kapellos \& Schaub, 1973 (P1.2 j)

Blackites piriformis (Pavsic in Khan et al., 1975) Aubry, 1999 (Pl.2 k)

Blackites singulus Bown and Jones, 2006 (Pl.2 1)

Blackites sp. (Pl.3a)

Family: Coccolithaceae Poche, 1913

Genus: Chiasmolithus Hay, Mohler \& Wade, 1966

Chiasmolithus gigas Bramlette \& Sullivan, 1961(Pl.3b)

Chiasmolithus grandis (Bramlette \& Riedel, 1954) Radomski, 1968(Pl.3c)

Genus: Coccolithus Schwarz, 1894

Coccolithus crassus Bramlette \& Sullivan, 1961(Pl.3d)

Coccolithus pelagicus (Wallich, 1877) Schiller, 1930(Pl.3e)

Coccolithus sp. (Pl.3 f)

Genus: Cruciplacolithus Hay \& Mohler in Hay et al., 1967

Cruciplacolithus frequens (Perch - Nielsen, 1977) Romein, 1979(Pl.3 g)

Genus: Erocsonia Black, 1964

Erocsonia formosa (Kamptner, 1963) Haq, 1971(Pl.3 h)

Family: Noelaerhabdaceae Jerkovic, 1970

Genus: Cyclicargolithus Bukry, 1971

Cyclicargolithus floridanus (Roth \& Hay in Hay et al., 1967) Bukry, 1971c (Pl.3 i)

Cyclicargolithus abisectus (Muller, 1970) Wise, 1973 (Pl.3 j)

Genus: Dictyococcites Black, 1967

Dictyococcites bisectus (Hay, Mohler \& Wade, 1966) Roth, 1970(Pl.3 k)

Dictyococcites scrippsae Bukry and Percival, 1971(Pl.3 1)

Genus: Reticulofenestra Hay, Mohler \& Wade, 1966

Reticulofenestra dictyoda (Deflandre in Deflandre \& Fert, 1954) Stradner in Stradner \& Edwards, 1968 (Pl.4 a)

Family: Prinsiaceae Hay \& Mohler, 1967

Genus: Prinsius Hay \& Mohler, 1967

Prinsius bisulcus (Stradner, 1963) Hay \& Mohler, 1967(Pl.4 b)

Genus: Toweius Hay \& Mohler, 1967

Toweius occultatus (Locker, 1967) Perch - Nielsen, 1971(Pl.4 c)

Toweius pertusus (Sullivan, 1965) Romein, 1979(Pl.4 d) 
Family: Papposphaeraceae Jordan \& Young, 1990

Genus: Thoracosphaera Kamptner, 1927

Thoracosphaera saxae Stradner, 1961(Pl.4 e)

II- Holococcoliths

Family: Calyptrosphaeraceae Boudreaux \& Hay, 1969

Genus: Zygrhablithus Deflandre, 1959

Zygrhablithus bijugatus (Deflandre in Deflandre \& Fert, 1954) Deflandre, 1959(Pl. 4 f)

Zygrhablithus sp. (Pl.4 g)

\section{III- Nannoliths}

Family: Braarudosphaeraceae Deflandre, 1947

Genus: $\boldsymbol{B r}$

Braarudosphaera bigelowii (Gran \& Braarud, 1935) Deflandre, 1947(Pl.4 h)

Braarudosphaera discula Bramlette \& Riedel, 1954 (Pl.4 i)

Braarudosphaera stylifera Troelsen \& Quadros, 1971(Pl.4 j)

Braarudosphaera sp. (Pl.4 k)

Genus: Micrantholithus Deflandre, 1950

Micrantholithus pinguis Bramlette \& Sullivan, 1961(Pl.4 1)

Micrantholithus sp. (P1.5a)

Family: Discoasteraceae Tan, 1927

Genus: Discoaster Tan, 1927

Discoaster adamanteus Bramlette \& Wilcoxon, 1967(P1.5 b)

Discoaster deflandrei Bramlette \& Riedel, 1954 (Pl.5 c)

Discoaster floreus Bystricka, 1964 (Pl.5 d)

Discoaster germanicus Martini, 1958 (P1.5 e)

Discoaster kuepperi Stradner, 1959 (Pl.5 f)

Discoaster martinii Stradner, 1959 (Pl.5 g)

Discoaster nodifer (Bramlette \& Riedel, 1954) Bukry, 1973(Pl.5 h)

Discoaster saipanensis Bramlette \& Riedel, 1954(Pl.5 i)

Discoaster sublodoensis Bramlette \& Sullivan, 1961 (Pl.5 j)

Discoaster triangularis Bystricka, 1966(Pl.5 k)

Discoaster trinus Stradner, 1961(P1.5 1)

Discoaster sp. (Pl.6 a)

Family: Heliolithaceae Hay \& Mohler, 1967

Genus: Heliolithus Bramlette \& Sullivan, 1961

Heliolithus cantabriae Perch-Nielsen, 1971(P1.6 b)

Family: Lithostromationaceae Deflandre, 1959

Genus: Rhomboaster Bramlette \& Sullivan, 1961

Rhomboaster cuspis Bramlette \& Sullivan, 1961(Pl.6 c) 
Genus: Tribrachiatus Shamrai, 1963

Tribrachiatus contortus (Stradner, 1958) Bukry, 1972(P1.6 d)

Family: Sphenolithaceae Deflandre, 1952

Genus: Sphenolithus Deflandre, 1952

Sphenolithus arthurii Bown, 2005 (Pl.6 e)

Sphenolithus editus Perch - Nielsen in Perch - Nielsen et al., 1978 (Pl.6 f)

Sphenolithus obtusus Bukry, 1971a (Pl.6 g)

Sphenolithus primus Perch-Nielsen, 1971(Pl.6 h)

Sphenolithus pseudoradians Bramlette \& Wilcoxon, 1967(Pl.6 i)

Sphenolithus radians Deflandre in Grasse, 1952(Pl.6 j)

Sphenolithus sp. (Pl.6 k)

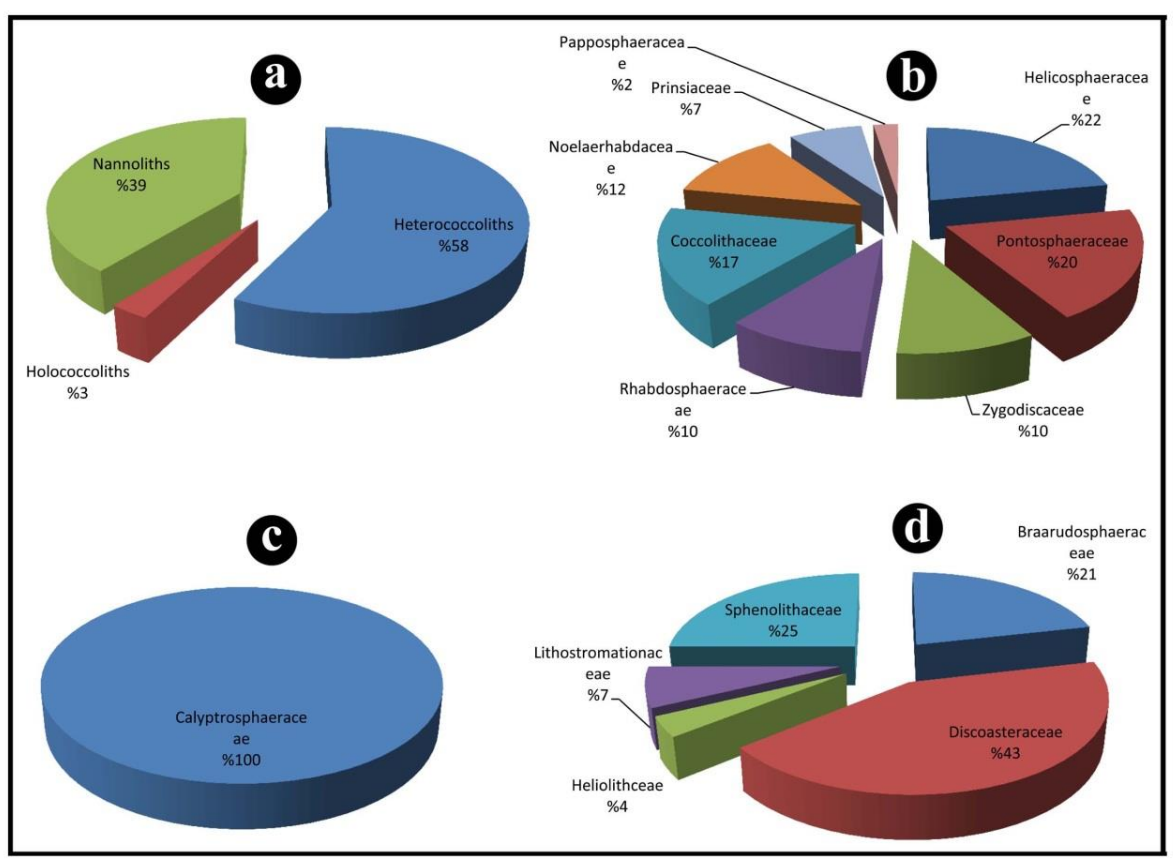

Diagram (1): Percentage of studied calcareous nannofossils taxa; (a) calcareous nannofossils groups, (b) Heterococcolithus families, (c) Holococcoliths families, (d) Nannoliths families. 


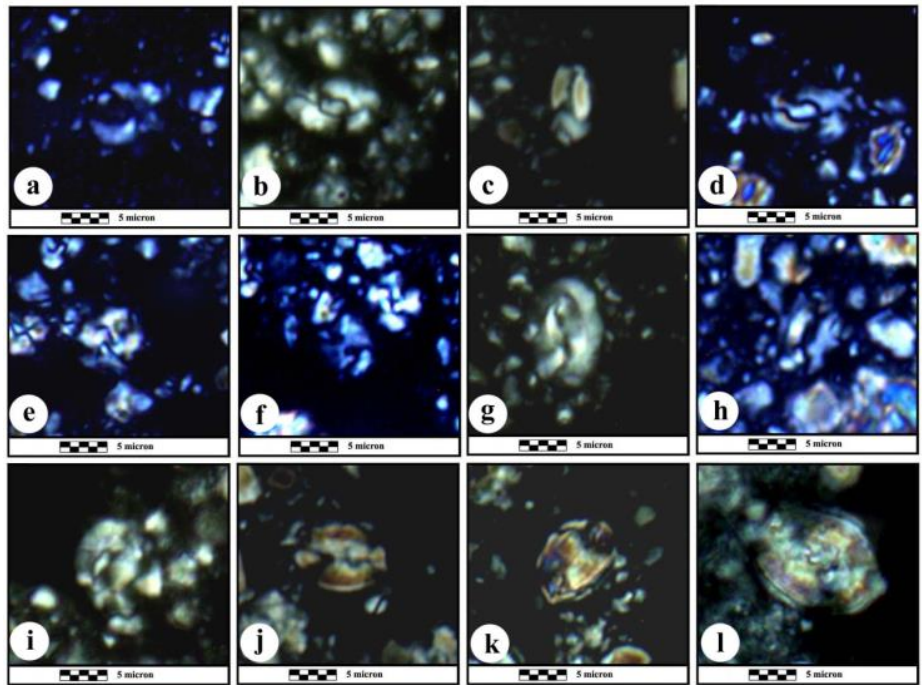

Plate (1): Cross-polarized photos of significant calcareous nannofossil taxa from Jaddala Formation; (a) Helicosphaera ampliaperta, (b) H. compacta, (c) $\mathrm{H}$. lophota, (d) $H$. papallata, (e) H. reticulate, (f) H. salebrosa, (g) $H$. seminulum, (h) H. wilcoxonii, (i) Helicosphaera sp., (j) Pontosphaera distincta, (k) P. fimbriata,(1) P. multipora. (Scale bar: 5 micron).

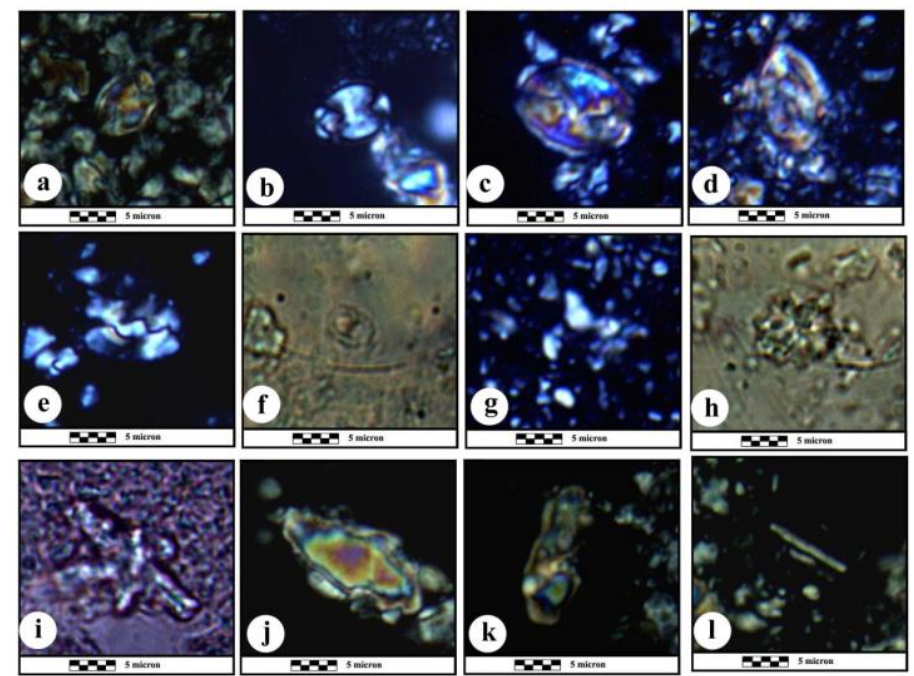

Plate (2): Cross-polarized and light photos of significant calcareous nannofossil taxa from Jaddala Formation. (a) Pontosphaera ocellata, (b) P. plana, (c) P. scissura, (d) Transversopontis prava, (e) Transversopontis sp.,(f) Lophodolithus nascens, (g) Nannotetrina alata,(h) N. cristata, (i) N. quadrata, (j) Blackites inflatus, (k) B. piriformis, (l) B. singulus. (Scale bar: 5 micron). 


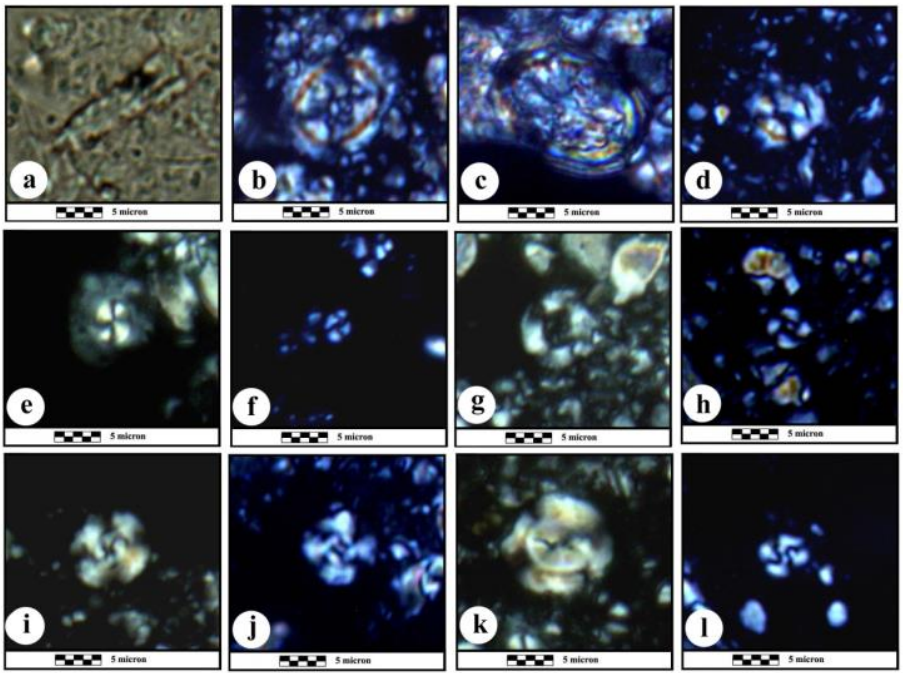

Plate (3): Cross-polarized and light photos of significant calcareous nannofossil taxa from Jaddala Formation; (a) Blackites sp., (b) Chiasmolithus gigas, (c) C. grandis, (d) Coccolithus crassus,(e) C. pelagicus, (f) Coccolithus sp.,(g) Cruciplacolithus frequens, (h) Erocsonia formosa, (i) Cyclicargolithus floridanus, (j) C. abisectus, (k) Dictyococcites bisectus, (l) D.scrippsae. (Scale bar: 5 micron)
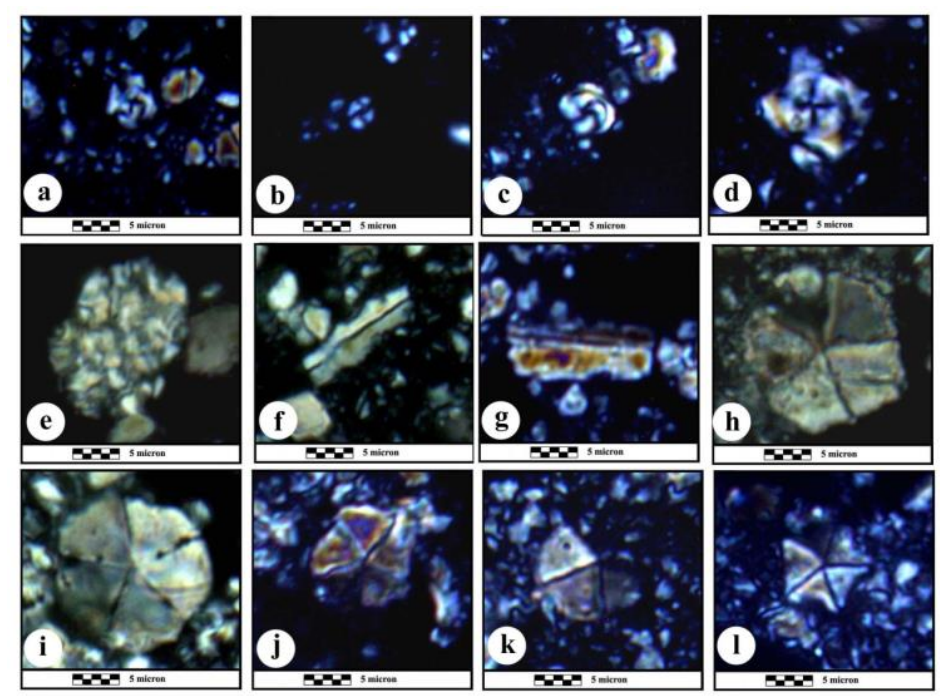

Plate (4): Cross-polarized photos of significant calcareous nannofossil taxa from Jaddala Formation; (a) Reticulofenestra dictyoda,(b) Prinsius bisulcus, (c) Toweius occultatus, (d) T. pertusus, (e) Thoracosphaera saxae, (f) Zygrhablithus bijugatus, (g) Zygrhablithus sp., (h) Braarudosphaera bigelowii, (i) B. discula, (j) B. stylifera, (k) Braarudosphaera sp.,(1) Micrantholithus pinguis. (Scale bar: 5 micron). 


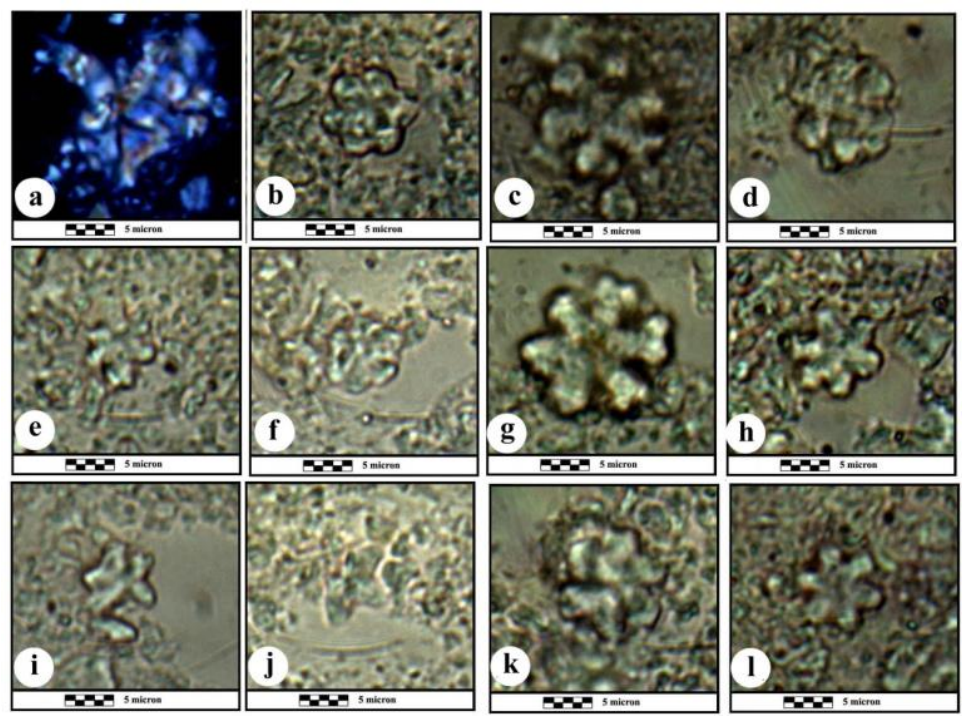

Plate (5): Cross-polarized and light photos of significant calcareous nannofossil taxa from Jaddala Formation; (a) Micrantholithus sp., (b) Discoaster adamanteus, (c) D. deflandrei, (d) D. floreus, (e) D. germanicus, (f) D. kuepperi, (g) D. martini, (h) D. nodifer, (i) D. saipanensis, (j) D. sublodoensis, (k) D. triangularis, (1) D. trinus. (Scale bar: 5 micron).

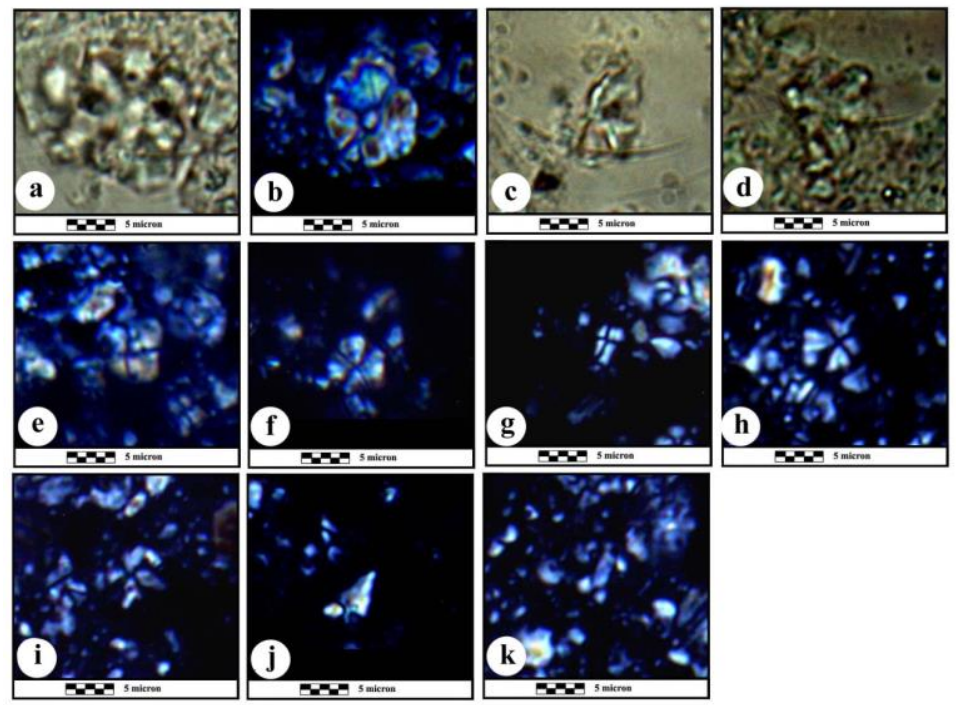

Plate (6): Cross-polarized and light photos of significant calcareous nannofossil taxa from Jaddala Formation; (a) Discoaster sp., (b) Heliolithus cantabriae, (c) Rhomboaster cuspis, (d) Tribrachiatus contortus, (e) Sphenolithus arthurii, (f) S. editus, (g) S. obtusus, (h) S. primus, (i) S. pseudoradians, (j) S. radians, (k) Sphenolithus sp.. (Scale bar: 5 micron). 


\section{B-Nannobiostratigraphy}

1- Reticulofenestra dictyoda Partial Range Biozone (CNE 5)

Definition: Partial range biozone of Reticulofenestra dictyoda.

Boundaries: The biozone is determined by the last occurrence of Tribrachiatus orthostylus, to the first occurrence of Discoaster sublodoensis.

Thickness: Between (1265-1250) m. depths.

Correlation and Discussion: This biozone is correlated to the biozone NP13 which was studied by Martini (1971) aged of the Early Eocene (Ypresian) and to biozone CP11which was studied by Okada and Bukry (1981) aged of the Early Eocene (Y prsian). This biozone corresponds to biozne CNE 5 which was studied by Agnini et al. (2014) aged of the Early Eocene (Y prsian); therefore; Early Eocene was suggested in this study. (Gradstein et al., 2012) (Diags.1-3).

2 - Discoaster sublodoensis Interval biozone (CNE 6-7)

Definition: Interval biozone of Discoaster sublodoensis.

Boundaries: The biozone is determined by the first occurrence of Discoaster sublodoensis to the first occurrence of Nannoterina cristata.

Thickness: Between (1250-1240) m. depths.

Correlation and Discussion: This biozone is correlated to the lower biozone of NP14 which was studied by Martini (1971) aged of the Early Eocene(Y presian) and to Subbiozone CP12a which studied by Okada and Bukry (1981) aged of the Early Eocene (Yprsian). This biozone corresponds to bioznes CNE 6 and 7 which was studied by Agnini et al. (2014) aged of the Early Eocene (Y prsian), therefore, Early Eocene was suggested in this study as well (Gradstein et al., 2012) (Diags.1-3).

\section{3 - Nannotetrina cristata Interval biozone (CNE 8)}

Definition: Interval biozone of Nannotetrina cristata.

Boundaries: The biozone is determined by the first occurrence of Nannotetrina cristata to the first occurrence of Nannotetrina alata.

Thickness: Between (1240-1225) m. depths.

Correlation and Discussion: This biozone is correlated to the upper biozone of NP14 which was studied by Martini (1971) aged of the Middle Eocene (Lutetian) and to Subzone CP12b which was studied by Okada and Bukry (1981) aged of the Middle Eocene (Lutetian) this biozone corresponds to biozne CNE 8 which was studied by Agnini et al. (2014) aged of the Middle Eocene (Lutetian) therefore, the middle Eocene was suggested in this study. (Gradstein et al., 2012) (Diags. 1-3).

4 - Nannotetrina alata Interval biozone (CNE 9)

Definition: Interval biozone of Nannotetrina alata.

Boundaries: The biozone is determined by the first occurrence of Nannotetrina alata to the first occurrence of Chiasmolithus gigas.

Thickness: Between (1225-1220) m. depths. 
Correlation and Discussion: This biozone is correlated to the lower biozone of NP15which was studied by Martini (1971) aged of the Middle Eocene (Lutetian) and to Subzone CP5 which was studied by Okada and Bukry (1981) aged of the Middle Eocene (Lutetian). This biozone corresponds to biozne CNE 9 which was studied by Agnini et al. (2014) aged of the Middle Eocene (Lutetian) therefore, the middle Eocene was suggested in this study (Gradstein et al., 2012) (Diags.1-3).

5 - Chiasmolithus gigas Range Biozone (CNE 10-11)

Definition: Range biozone of Chiasmolithus gigas.

Boundaries: The biozone determinate by the first occurrence of Chiasmolithus gigas to the last occurrence of Chiasmolithus gigas.

Thickness: Between (1220-1195) m. depths.

Correlation and Discussion: This biozone is correlated to the middle biozoneof NP15 which was studied by Martini (1971) aged of the Middle Eocene (Lutetian) and Subzone CP13b, which was studied by Okada and Bukry (1981) aged of the Middle Eocene (Lutetian). This biozone corresponds to biozones CNE 9 and 10 which was studied by Agnini et al. (2014) aged of the Middle Eocene (Lutetian) therefore, the middle Eocene was suggested in this study as well. (Gradstein et al., 2012) (Diags. 1-3).

\section{CONCLUSIONS}

The Jaddala Formation in (Aj-10) well has five biostratigraphic zones, which include the following: Reticulofenestra dictyoda Partial Range Biozone (CNE 5); Discoaster sublodoensis Interval biozone (CNE 6-7); Nannotetrina cristata Interval biozone (CNE 8); Nannotetrina alata Interval biozone (CNE 9) and Chiasmolithus gigas Range Biozone (CNE 10-11). These Biozones are correlated with other calcareous nannofossils biozones from both local and regional sections leading to conclude that the age of the studied section is Early to Middle Eocene (Yprsian toLutetian). 
Calcareous nannofossils biostratigraphy of Jaddala

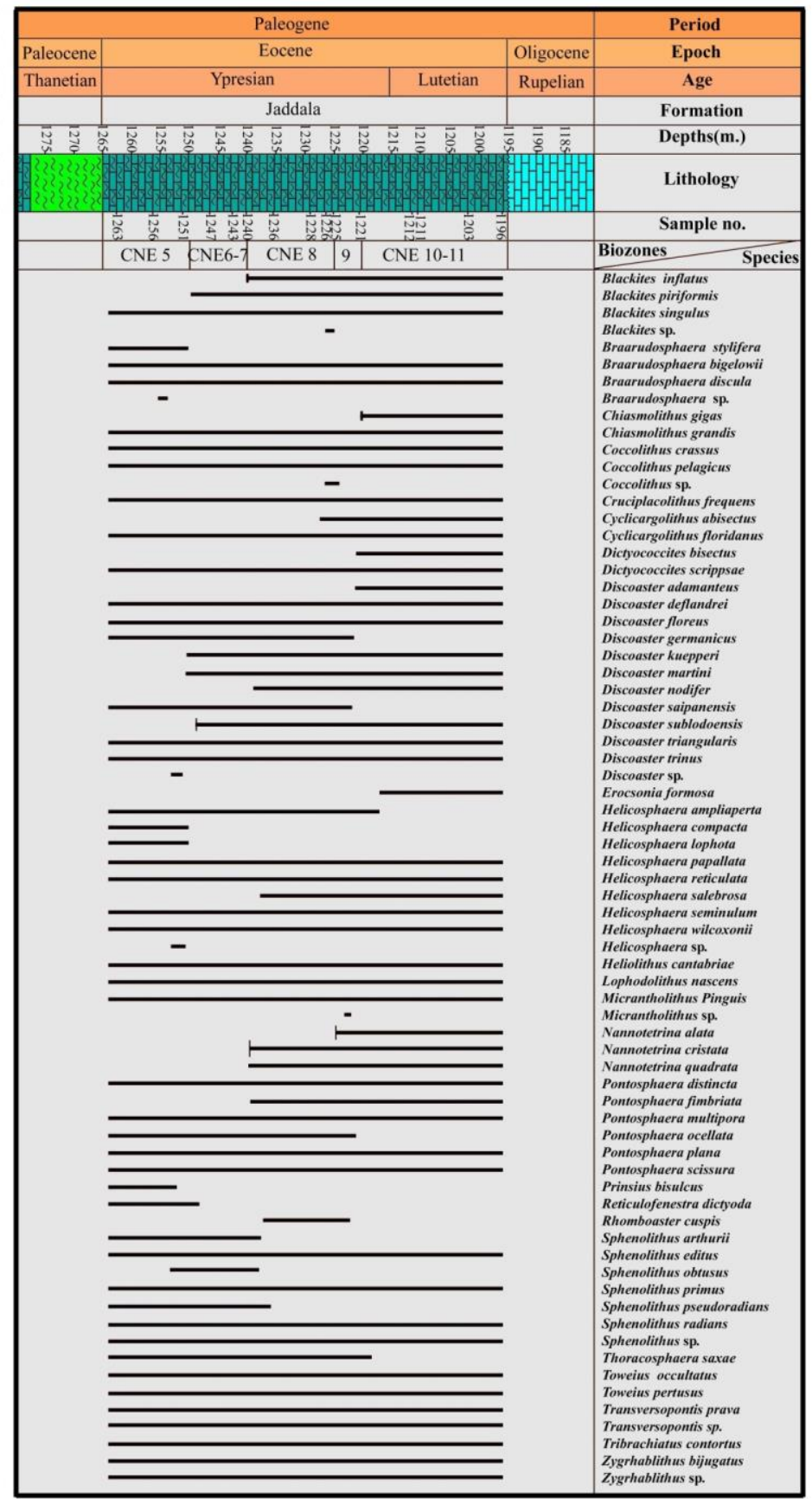

Diagram (2): Range chart of calcareous nannofossils throughout studied section. 
Al-Nuaimi and Al-Badrani

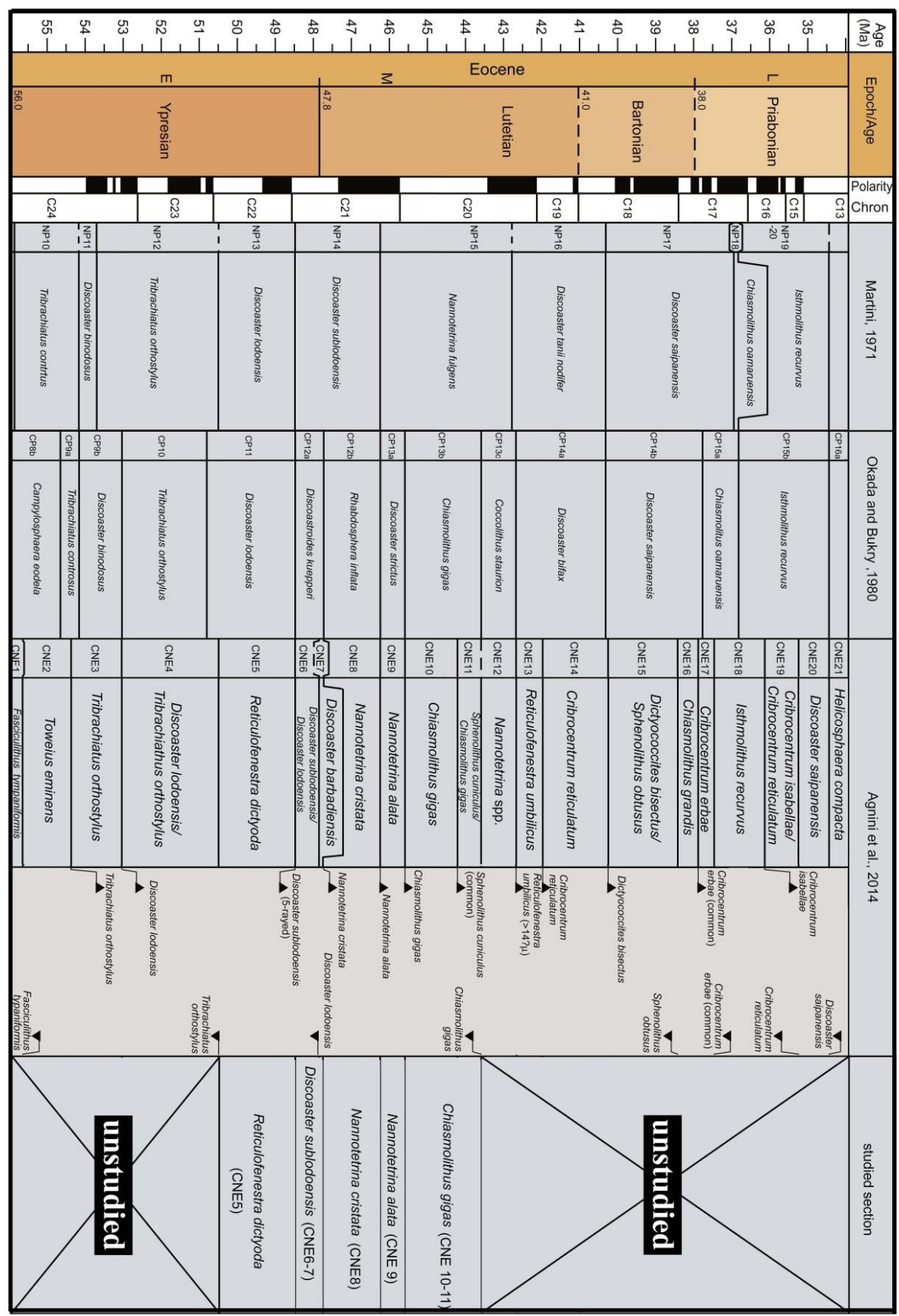

Diagram (3): correlated chart of calcareous nannofossils biozones for studied section 


\section{ACKNOWLEDGMENTS}

We would like to thank Mosul University, College of Science, Geology Department for supporting the authors by offering laboratory to accomplish this work.

\section{LITEREATURE CITED}

Al-Badrani, O. A. 2007.The study of calcareous nannofossils of Middle Eocene - Lower Miocene successions in Sinjar Anticline section, Northwest Iraq. Unpublished Ph.D. Thesis, College of Science, University of Mosul, 119 pp (In Arabic).

Al-Badrani, O. A. 2011. Nannobiostratigraphy of Jaddala Formation in well (Kh 12/7) West Iraq. Iraqi Journal of Earth Sciences, 11(1): 71 - 84.

Al-Badrani, O. A. and Al-Nima, R. R. 2010. Recognition between Eudiscoaster and Heliodiscoaster using Competitive Neural Network. Iraqi Journal of Earth Sciences, 10(2): $97-110$.

Al-Badrani, O. A. and Al-Ubaidi, M. H. 2012. Transversopontis omarians sp. nov. Calcareous nannofossils from Jaddala Formation (Eocene) in Dh.1 well, Central Iraq. Iraqi Journal of Earth Sciences, 12(3): 73 - 78.

Al-Badrani, O. A. and Al-Zubaidi, A. S. 2015.Nannobiostratigraphy of Jaddala Formation (type section), Sinjar anticline, NW Iraq. Journal of Nannoplankton Researches, 35, special Issue (Abstracts), 15pp.

Al-Badrani, O. A. and Al-Zubaidi, A. S. 2017. Two new species of calcareous nannofossils from Jaddala Formation, type section, Northwestern Iraq. Kirkuk University Journal I Scientific Studies, 12 (4): 1 - 12.

Al-Badrani, O. A. and Al-Zubaidi, A. S. 2019 a. Paleoclimatology evidence of Eocene from Jaddala Formation in Northwestern Iraq. In: Zhang, Z., Khelifi, N., Mezghani, A. and Heggy, E..Patterns and Mechanisms of Climate, Paleoclimate and Paleoenvironmental Changes from Low-Latitude Region, Springer Nature, 188pp.

Al-Badrani, O. A. and Al-Zubaidi, A. S. 2019 b. Paleogene Calcareous Nannofossils. Lambert Academic Publishing, 104 pp.

Agnini, C., Fornaciari, E., Raffi, I., Catanzariti, R., Pa“like, H., Backman, J. and Rio, D. 2014. Biozonation and biochronology of Paleogene calcareous nannofossils from low and middle latitudes. Newsletters on Stratigraphy, 47(2): 131-181.

Armstrong, H. A. and Brasier, M. D. 2005. Microfossils, second edition. Black well publishing, Oxford, $304 \mathrm{pp}$. 
Bellen, R. C. van, Dunnington, H. V., Wetzel, R. and Morton, D. M. 1959. Lexique stratigraphique international, Vol. III: Asie , Fascicule 10 a, Iraq, 333pp.

Bramlette, M. N. and Sullivan, F. R. 1961. Coccolithophorids and related nannoplankton of the early Tertiary in California. Micropaleontology, 7(2): 129188.

Buday, R. T. and Jassim, S. Z. 1987.The Regional Geology of Iraq, 2, Tectonism, Magmatism and Metamorphism, Baghdad, $352 \mathrm{pp}$.

Bukry, D. 1971.Coccolith stratigraphy Leg. 6. Intial Report of the Deep Sea Drilling Project, VI: 965-1004.

Bukry, D. 1973. Coccolith stratigraphy, eastern equatorial Pacific, Leg 16 Deep Sea Drilling Project. In: van Andel, T. H.,1-Health, G.R., et al., Initial report of the Deep Sea Drilling Project,XVI. Washington, D. C.: US. Gov. Printing office, p. 6571-6531.

Gradstein, F. M., Ogg, J. G., Schmitz, M. D. and Ogg, G. M. 2012. The geologic time scale 2012. Elsevier, $1^{\text {st }}$ edition, 1167 pp.

Haq, B. U. 1971. Paleogene calcareous nannoflora Parts I-IV. Stockholm Contribution Geology, 25:1-158.

Haq, B. U. and Lohmann, G. P. 1976. Early Cenozoic calcareous Nannoplankton Biogeography of the Atlantic Ocean. Marine Micropaleontology, 1: 119 -194.

Hay, W. W. and Mohler, H. P. 1967.Calcareous, nannoplankton from Early Tertiary Rocks at Pont Labau, France, and Paleocene - Early Eocene Correlations. Journal Paleontology, 41(6): 1505 -1541.

Hay, W. W., Mohler, H. P., Roth, P. H., Schmidt, R. R. and Boudreaux, J. E. 1967.Calcareous Nannoplankton Zonation of the Cenozoic of the Gulf Coast and Caribbean-Antillean Area and Transoceanic Correlations. Gulf Coast Association Geological Societies Transactions, 17: 428-480.

Jassim, S. Z. and Goff, J. 2006. Geology of Iraq. Dolin, Prague and Moravian Museum, Brno, $341 \mathrm{pp}$.

Martini, E.1960. Braardosphaaeriden, discoasteriden und verwandte fomenausdem rupelton des mainzer beckens. Naturschutz. Hessischesfür Landessamt Bodenflächenkataster, 88: $65-87$. 
Martini, E. 1971. Standard Tertiary and Quaternary Calcareous Nannoplankton Zonation. Proceedings of the 2nd Planktonic Conference, Roma, 1970, p. 739785 .

Okada, H. and Bukry, D.1980. Supplementary modification and introduction of code numbers to low-latitude coccolith biostratigraphy zonation (Bukry, 1973, 1975). Marine Micropaleontology, 5(3): 321- 326.

Perch-Nielsen, K. 1971 a. Elektronemikroskopische Untersuchngenan Coccolithen und verwandten Formenausdem Eozan von Danemark. det Kongelige Danske Videnskabernes Selskab Biol. Skrifter,18(3):1-76.

Perch-Nielsen, K.1971 b. Neue Coccolithen ausdem Palaozan von Danemark, der Bucht von Biskaya und demEozan der Labrador See. Bulletin of the Geological Society of Denmark, 21: 51-66.

Perch-Nielsen, K.1972. Remark on late cretaceous to Pleistocene coccoliths from the North Atlantic. Initial Reports of the Deep Sea Drilling Project, 12: 1003 -1069.

Perch-Nielsen, K. 1977. Albian to Pleistocene calcareous nannofossils from the western South Atlantic. Initial Reports of the Deep Sea Drilling Project, 39: 699-823.

Perch-Nielsen, K. 1984.Validation of New combinations. INA Newsletter, 6(1): 42-46.

Perch-Nielsen, K. 1985.Cenozoic calcareous nannofossils. In: Bolli, H. M., Saundes, J. B.and Perch-Nielsen, K. (eds.), Plankton stratigraphy. Cambridge University Press, Cambridge, p. 427-554.

Radomski, A. 1968. Calcareous nannoplankton zones in palcogeneof the Western Polish Carpatians. Rocznik Polskie Towarzystwo Geologiczne, 38: 545-605.

Romein, A. J. 1979. Lineages in early paleogene calcareous nannoplankton. Utrecht Micropaleontological Bulletin, 22: 1-231.

Roth, P. H. 1970. Oligocene calcareous nannoplankton biostratigraphy Eclogae Geologicae Helvetiae, 63: 799-881.

Schiller, J. 1930. Coccolithineae. In: Rabenhorst, L. (ed.) Kryptogamen-Flora von Deutschland, Österreich und der Schweiz. Akademische Verlagsgesellschaft, Leipzig, p. 89-267.

Stradner, H. 1958. Die fossi1en Discoasteriden Osterreichs. I.Tail Erdoel-Zeitschrift, 74(6): $178-188$. 
Stradner, H. and Edwards, A. R. 1968. Electron microscopic studies on upper Eocene cocoliths from Omauru Diatomite, New Zealand. Jahrbuch der Geologischen Bundesanstalt (Wien), special, 13:1-66.

Young, J. R. and Bown, P. R. 1997. Cenozoic calcareous nannoplankton classification. Journal of Plankton Researches, 19: 36-47.

Tan, S. H. 1927. Discoaster idaeincertaesedis. Proceedings of the Koninklijke Nederlandse Akademie van Wetenschappente Amsterdam, 30(3): 411-419. 


$$
\begin{aligned}
& \text { الطباقية الحياتية لمتحجرات النانو الكلسية لتكوين جدالة في بئر(Aj-10) } \\
& \text { وسط العراق الق الن }
\end{aligned}
$$

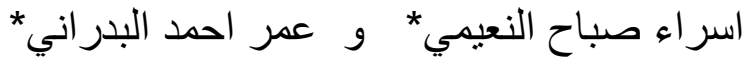

$$
\begin{aligned}
& \text { * قسم علوم الارض، كلية العلوم، جامعة الموصل، الموصل، العراق. }
\end{aligned}
$$

(1)Reticulofenestra dictyoda Partial Range Biozone (CNE 5), (2)Discoaster sublodoensis Interval biozone (CNE 6-7), (3)Nannotetrina cristata Interval biozone (CNE 8), (4)Nannotetrina alata Interval biozone (CNE 9), (5)Chiasmolithus gigas Range Biozone (CNE 1011).

$$
\begin{aligned}
& \text { قورنت هذه الانطقة الحياتية بمثيلاتها قادت الى تحيد عمر التكوين في } \\
& \text { هذا المقطع بالايوسين الاوسط (الييرسييان الى اللونيشيان). }
\end{aligned}
$$

